Physical Geography; Cartography; Geographic Information Systems \& Spatial Planing

\title{
EFFECT OF A RESERVOIR OPERATION ON RELATIONS BETWEEN RIVER WATER TEMPERATURE AND AIR TEMPERATURE
}

DOI: http://dx.doi.org/10.18509/GBP.2016.10
UDC: $556.113 .04(438: 234.4)$

\author{
dr Lukasz Wiejaczka \\ dr Małgorzata Kijowska-Strugała \\ Polish Academy of Sciences, Institute of Geography and Spatial Organization
}

\begin{abstract}
The article presents relations between water temperature in the Ropa river (the Polish Carpathians) and the air temperature in the longitudinal profile of the river, taking into account the distortions resulting from the operation of Klimkówka reservoir. The analysis is based on measurements of water and air temperature of the river upstream and downstream of the reservoir in various air temperature conditions in the daily and annual cycle. The observed disturbances in the relation between water and air temperature result from a transformation of the natural thermal regime of the river downstream of the dam. Therefore, in any research into relations between river water temperature and air temperature, the effect of reservoirs on river water temperature must be taken into consideration. It is important for predicting the impact of potential climate change on river ecosystems.
\end{abstract}

Keywords: water temperature, air temperature, river, reservoir, Carpathians

\section{INTRODUCTION}

Water temperature is a key factor regulating biological life and all processes occurring in the aquatic environment of rivers $[1,2]$ and it also has a key role in research on the impact of potential climate change on aquatic ecosystems [3]. In natural conditions, annual thermal regime of rivers is affected mainly by meteorological conditions in general and air temperature in particular [4]. According to [5], water temperature in a river changes as a result of heat exchange between the water and the air until equilibrium temperature is reached. Equilibrium temperature is a hypothetical water temperature such that there is no heat exchange between the water and the air.

Water emerging to the surface of the ground in the headwaters of a river, with its temperature determined by the thermal conditions of the ground, becomes subjected to atmospheric conditions which become the key factor shaping the river temperature. The river water temperature then grows with the distance from the source and clearly approaches the mean ambient air temperature for the given period and area. The higher the discharge, the slower the water temperature in the river grows along its course [3]. In rivers largely fed by groundwater, the impact of air temperature on the water temperature may be abated. Groundwater temperature is a natural factor distorting the relation between water temperature and air temperature [6].

The anthropogenic factor distorting the relations between river water temperature and air temperature is the presence of dam reservoirs [7, 8]. Thermal regime in the river downstream of the reservoir are significantly affected by thermal processes evolving in the reservoir over the year [7,9]. 
This study aims to present the natural evolution of water temperature along the course of a mountain river under the influence of the air temperature and to demonstrate the distortions occurring in the relation between the water and ambient air temperature in the longitudinal profile of the river as a result of the operation of a reservoir.

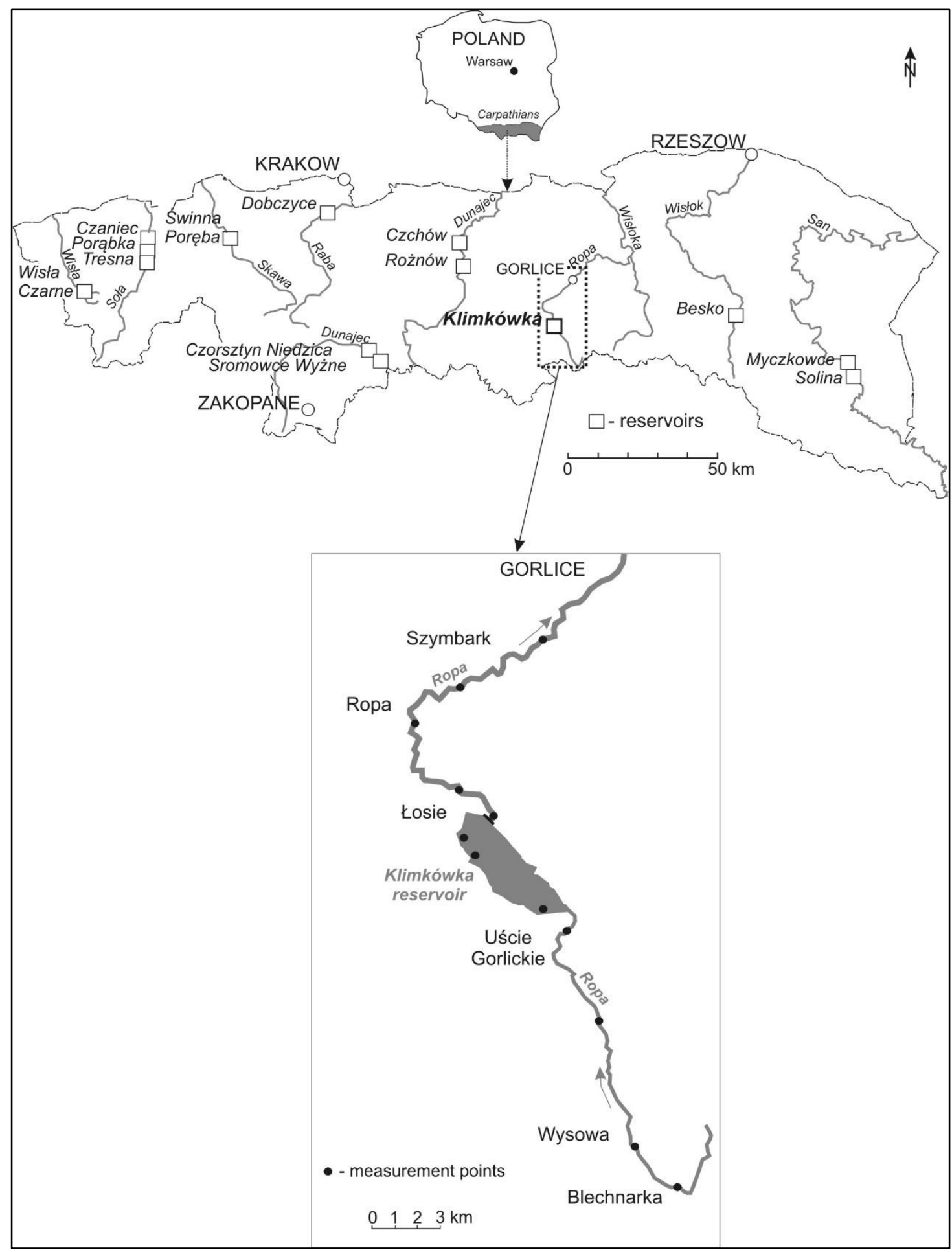

Figure 1. Area of the research and the measurement points locations 


\section{RESEARCH AREA AND METHODOLOGY}

The research was carried out on the Ropa river located in the basin of the upper Vistula river (Fig. 1). In its upper course, the Ropa drains the western part of the Low Beskid mountains, in the Polish Carpathians. Its total length is $80 \mathrm{~km}$ and the catchment surface of is $974 \mathrm{~km}^{2}$. The Ropa hydrological regime is heterogenous, with floods in spring, summer and winter. The river is fed by rain, groundwater and snow.

Klimkówka reservoir is one of about a dozen dam reservoirs in the Polish Carpathians. It was commissioned in 1994. The dam, with a height of $33 \mathrm{~m}$, is located at $54.4 \mathrm{~km}$ point of the Ropa course. The total capacity of the reservoir is 43.5 million $\mathrm{m}^{3}$ and its surface is approx. $3 \mathrm{~km}^{2}$. Its maximum depth is approx. $30 \mathrm{~m}$. The main purpose of the reservoir is increasing the low natural flow of the river, and flood protection. The guaranteed outflow from the reservoir is $2.0 \mathrm{~m}^{3} \cdot \mathrm{s}^{-1}$. Between 2007 and 2011 , the average annual discharge of the Ropa was $1.30 \mathrm{~m}^{3} \cdot \mathrm{s}^{-1}$ upstream of the reservoir and $3.28 \mathrm{~m}^{3} \cdot \mathrm{s}^{-1}$ downstream of it.

The measurements of the Ropa water temperature and the air temperature were taken in 2010, at different air temperature conditions, in various seasons (summer, autumn, winter) and times of day (morning and afternoon), at the approx. 40-km-long river section (Fig. 1). The measurements were carried out at five locations on the river upstream of the reservoir and five locations on the river downstream of it. Additionally, measurements were taken at three locations within Klimkówka reservoir itself, near its left bank. Water temperature was measured with an electronic thermometer and air temperature was measured with a mercury thermometer, at a distance of between 2 and $20 \mathrm{~m}$ from the river bank and at the elevation of approx. $1.5 \mathrm{~m}$ above the ground.

\section{RESULTS AND DISCUSSION}

\section{Water temperature patterns in the longitudinal profile of the Ropa river, undistorted by Klimkówka reservoir}

The Ropa water temperature dynamics in the longitudinal profile of the river from Wysowa to Szymbark in the natural conditions (i.e. before Klimkówka reservoir was constructed) is presented by [10], (Fig. 2). The measurements were taken at the time of maximum summer air temperatures. The Ropa temperature profile patterns based on measurements taken in 1971 show an upward trend of the water temperature in the entire profile from Wysowa to Szymbark, irrespective of the weather conditions. The highest increase of the water temperature in the Ropa river with the distance from the source was observed at the time of clear sky, maximum solar radiation and maximum daily values of air temperature (approx. $30{ }^{\circ} \mathrm{C}$ along the entire profile): the difference of water temperature between the starting point and the final point of the measurement profile was $8^{\circ} \mathrm{C}$. The key factor determining the river water temperature over the river length at this section was the air temperature.

According to [10], the water temperature in the Ropa river followed the ambient air temperature changes with a lag of 2 to 3 hours. There were two distinct periods in the Ropa water temperature evolution pattern: heat absorption during the daytime and heat radiation during the night time. The scale of those changes depended on the meteorological conditions of the day and the local characteristics of the drainage catchment and the river channel. 


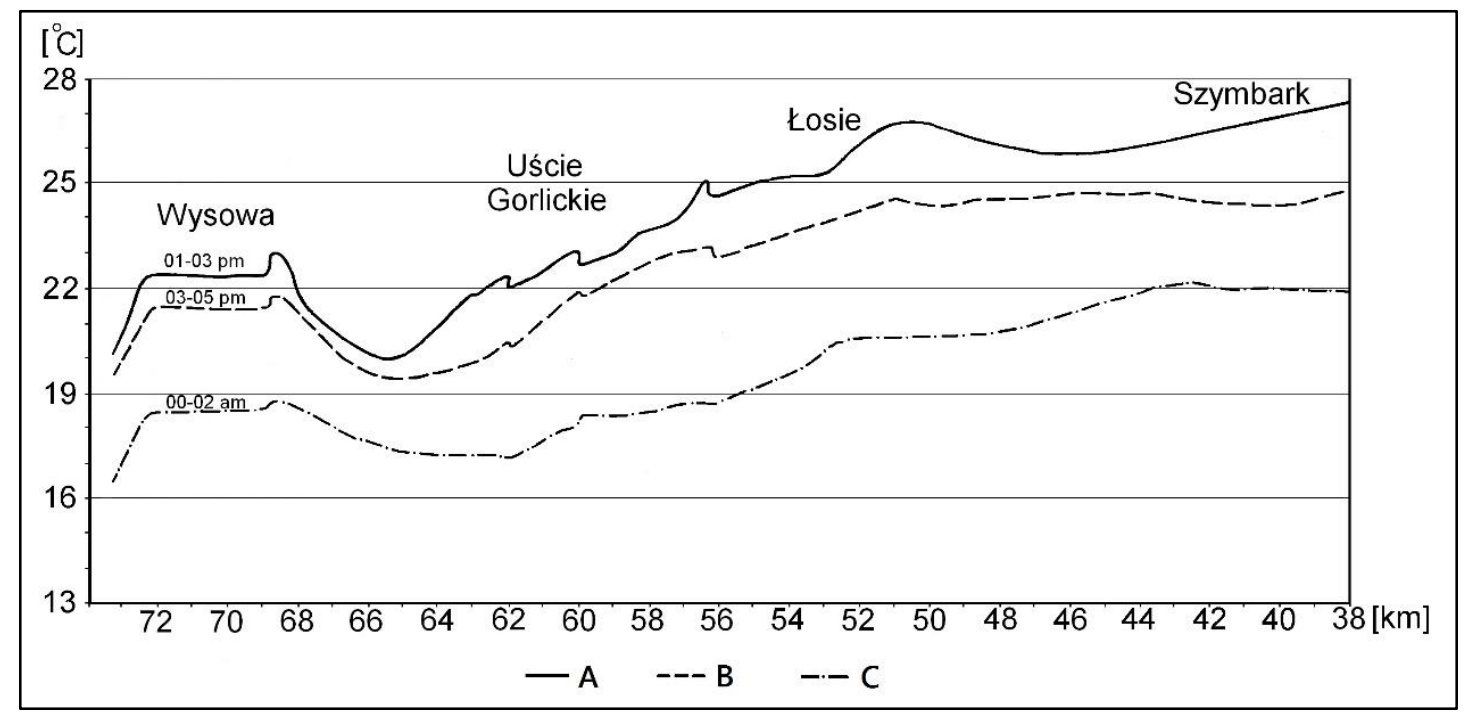

Figure 2. Water temperature patterns in the longitudinal profile of the Ropa river in 1971, undistorted by Klimkówka reservoir, A - 29 July, B - 30 July, C- 31 July [10]

Water and air temperature patterns in the longitudinal profile of the Ropa river, (with Klimkówka reservoir)

\section{Measurements on 16 July 2010 between 04:00 and 06:30am}

Measurements of the Ropa water temperature and air temperature along the river (Fig. 3) on a summer day, in the early morning hours, at the time of minimum daily temperatures, showed that, at the first measurement location in Blechnarka, the water temperature was $1.7^{\circ} \mathrm{C}$ lower than the air temperature. In the headwaters, the river water temperature is determined by the groundwater feeding it. Further downstream, a growing influence of the air temperature was observed. The relation between the water temperature and the air temperature may be described as directly proportional. The increase of the air temperature was matched by the increase of the water temperature, with the difference between them at 2.1 to $2.4^{\circ} \mathrm{C}$. The water temperature was higher than the air temperature as water, being a poor heat conductor, warms up slower than air during the day but also cools down slower than air during the night. Directly upstream from the backwater of the reservoir, the difference between the Ropa water temperature and the air temperature was up to $3.9^{\circ} \mathrm{C}$. The surface stratum of water in the reservoir had high temperature $\left(23-24^{\circ} \mathrm{C}\right)$, as it had absorbed heat over the few preceding days, when the air temperature exceeded $30^{\circ} \mathrm{C}$. The recorded temperature of water in the reservoir was higher than the air temperature by 6.1 to $8.8^{\circ} \mathrm{C}$. Downstream of the dam, the difference of temperatures was reversed in comparison to the river section upstream of the reservoir: the river water temperature was significantly lower than the air temperature and was growing slowly downstream. The temperature of water flowing out from the reservoir (from its bottom stratum) was $7.3^{\circ} \mathrm{C}$ lower than the temperature of the inflowing water. Thus, Klimkówka reservoir disrupted the thermal continuity of the Ropa river. Downstream of the dam, the air temperature gradually affected the water temperature and the relation was directly proportional. However, the temperature difference was far higher than upstream of the reservoir: between 3.9 and $5.6^{\circ} \mathrm{C}$. 


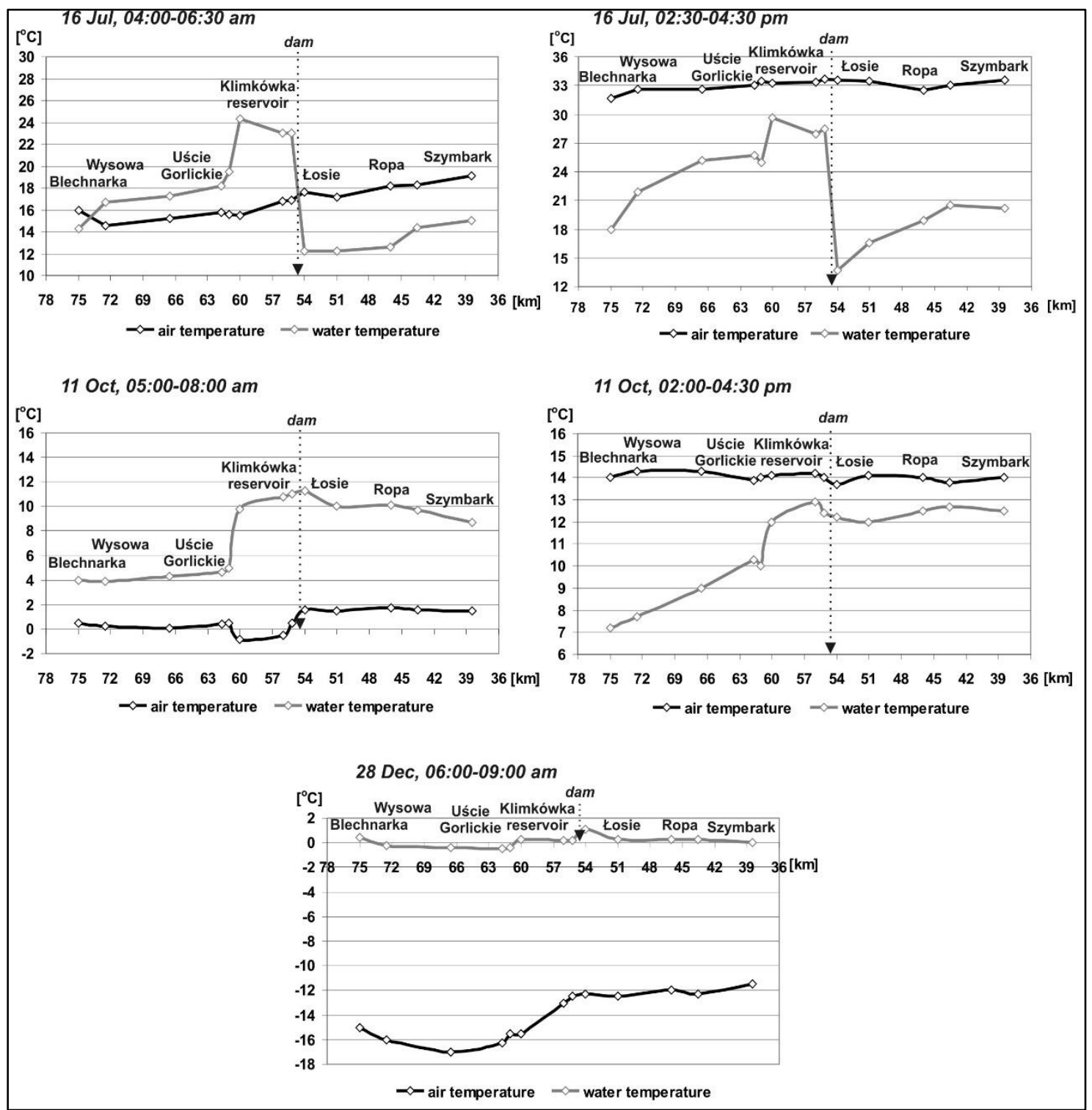

Figure 3. Water and air temperature patterns in the longitudinal profile of the Ropa river (measurements taken in 2010)

\section{Measurements on 16 July 2010 between 2:30 and 4:30 pm}

Measurements of the water temperature of the Ropa river and air temperature taken in summer, in the afternoon, at the time of maximum daily air temperature (Fig. 3), showed a low variation of air temperature over the length of the profile, although the temperatures were very high $\left(31.6-33.7^{\circ} \mathrm{C}\right)$. On the other hand, the Ropa water temperature showed high variation and was significantly lower than the air temperature. Upstream of the reservoir, between Blechnarka and Uście Gorlickie, the water temperature grew rapidly along the course of the river, from 17.9 to $25.7^{\circ} \mathrm{C}$, due to high air temperatures. In the surface stratum of the reservoir, the water temperature measured near the bank was even higher, between 27.9 and $29.6^{\circ} \mathrm{C}$. Upstream of the reservoir, the difference between the river water temperature and the air temperature in each location ranged from 7.3 and $13.7^{\circ} \mathrm{C}$. The difference between the water temperature in the reservoir and the air temperature was much lower: between 3.6 and $5.4^{\circ} \mathrm{C}$. The temperature of water flowing out from the reservoir, at $13.7^{\circ} \mathrm{C}$, was lower by $11.3^{\circ} \mathrm{C}$ than the temperature of inflowing 
water and as much as $14.8^{\circ} \mathrm{C}$ lower than the temperature of water in the surface stratum of the reservoir. This resulted from thermal stratification having developed in Klimkówka reservoir in the summertime: warmer water was stagnating in the surface stratum, and cooler water in the bottom stratum. In the present case too, the thermal continuity of the Ropa river was disrupted. Downstream of the reservoir, the river water temperature grew significantly with its course, from 13.7 to $20.5^{\circ} \mathrm{C}$. Differences of the Ropa water temperature and the ambient air temperature in each measurement location downstream of the reservoir ranged from $19.9^{\circ} \mathrm{C}$ near the dam to $12.5^{\circ} \mathrm{C}$ in Szymbark. Noticeably, even as far downstream as Szymbark the river water temperature did not reach the values observed upstream of the reservoir and was lower by $12.0^{\circ} \mathrm{C}$ (near the dam) and $7.0^{\circ} \mathrm{C}$ (in Szymbark) than recorded by [10] (before the reservoir was constructed).

\section{Measurements on 11 October 2010 between 05:00 and 08:00am}

During morning measurements, at the time of minimum daily air temperatures, the temperature of the Ropa water was significantly lower than the air temperature in the length of the longitudinal profile (Fig. 3). Upstream of Klimkówka reservoir there was little variation of the Ropa water temperature as well as the air temperature along the river course. The river water temperatures ranged from 3.9 to $5.0^{\circ} \mathrm{C}$ and the air temperatures ranged from 0.1 to $0.5^{\circ} \mathrm{C}$. The differences at each measurement location ranged from 3.5 to $4.5^{\circ} \mathrm{C}$. Measurements taken in Klimkówka reservoir showed that despite the air temperature being in the range of -0.8 to $0.5^{\circ} \mathrm{C}$ (the temperature was below freezing near the backwater, with hoar frost visible on the grass), the water temperature in the reservoir ranged from 9.8 to $11.0^{\circ} \mathrm{C}$. The temperature of water flowing out from the reservoir was $11.3^{\circ} \mathrm{C}$, which was $6.3^{\circ} \mathrm{C}$ higher than the temperature of the inflowing water. This means that the thermal continuity of the river was disrupted. The increase of water temperature, due to the conditions in the reservoir, was disproportionately high in relation to the natural temperature variation upstream of the reservoir. Downstream of the reservoir, the river water temperature decreased gradually with its course all the way to the end of the measurement profile (a decrease of $8.7^{\circ} \mathrm{C}$ ), which was due to low air temperature (from 1.5 to $\left.1.7^{\circ} \mathrm{C}\right)$.

\section{Measurements on 11 October 2010 between 2:00 and 4:30pm}

In the afternoon, at the time of maximum daily air temperatures, the air temperature along the longitudinal profile was stable and homogenous, in the narrow interval between 13.7 and $14.3^{\circ} \mathrm{C}$ (Fig. 3). The river water temperature showed a far higher variation, especially upstream of the reservoir, where it grew with the course of the river from 7.2 to $10.3^{\circ} \mathrm{C}$ ). The difference between water and air temperature ranged from $6.8^{\circ} \mathrm{C}$ at the initial point of the measurement profile to $3.6^{\circ} \mathrm{C}$ directly upstream of Klimkówka reservoir. Within the reservoir, the temperature of water in the surface stratum was even higher: 12.0$12.9^{\circ} \mathrm{C}$, i.e. only $1.3-2.1^{\circ} \mathrm{C}$ lower than the air temperature. The water flowing out from the bottom stratum of the reservoir was $2.0^{\circ} \mathrm{C}$ warmer than the water flowing into the reservoir. It was cooler than the water in the surface stratum by a few tenths of a degree Celsius only. Thus, the water temperature in the reservoir was homogenous at the time of the measurement. In such conditions, the thermal continuity of the river was disrupted too, although the scale of the disruption was less pronounced. Downstream of the reservoir, the river water temperature was stable along its course at $12.0-12.7^{\circ} \mathrm{C}$ and the 
recorded differences in relation to the air temperature at each measurement point location were between 1.2 and $2.1^{\circ} \mathrm{C}$.

\section{Measurements on 28 December 2010 between 06:00 and 09:00am}

Winter measurements were taken in the morning hours only, with extremely low air temperatures (Fig. 3). The results showed low variation of water temperature along its course: between $-0.5^{\circ} \mathrm{C}$ and $1.1^{\circ} \mathrm{C}$, which is entirely understandable given the air temperature. There was more variation in the air temperature between the measurement points locations, particularly upstream of the reservoir, where initially there was a decrease in air temperature with the river course, from -15.0 to $-17.0^{\circ} \mathrm{C}$, then a growth to $-15.5^{\circ} \mathrm{C}$. The growth continued along the reservoir, down to the measurement location directly downstream of the dam, where the air temperature was $-12.3^{\circ} \mathrm{C}$. Further downstream, the air temperature was stable in the narrow interval between -12.3 and $11.5^{\circ} \mathrm{C}$. The water temperature at the first measurement location in Blechnarka was $0.4^{\circ} \mathrm{C}$. The temperature was above freezing due to the river being fed with groundwater. Further along the river course, the air temperature became the key determinant of the river water temperature, causing the water to cool down to $0^{\circ} \mathrm{C}$, as evidenced by partial ice cover appearing. The observed differences between the water temperature and air temperature reached $15.0-17.0^{\circ} \mathrm{C}$. In the surface stratum of Klimkówka reservoir, the temperature of water (measured underneath the ice cover approx. $5 \mathrm{~cm}$ thick) was above freezing $(0.2-$ $\left.0.3^{\circ} \mathrm{C}\right)$. The water flowing out of the reservoir was warmer $\left(1.1^{\circ} \mathrm{C}\right)$ as a result of winter stratification of the reservoir: the water was cooler in the upper strata and warmer in the lower strata. Downstream of the reservoir, the water had temperatures above freezing $\left(0.3^{\circ} \mathrm{C}\right)$ over the course of more than ten kilometres. Due to the influence of air temperature being well below freezing, at the end of the measurement profile the water temperature cooled down to $0^{\circ} \mathrm{C}$. Noticeably, downstream of the reservoir the first ice forms were only observed as far as $10 \mathrm{~km}$ from the dam. This shows that the thermal and ice-cover continuity of the river was disrupted.

\section{CONCLUSIONS}

The analysis of water and air temperature variations in the longitudinal profile of the Ropa river allows the following conclusions to be drawn:

1. Upstream of the reservoir, with the air temperature above $0^{\circ} \mathrm{C}$, the river water temperature maintains its natural upward trend with growing distance from the source. It is due to the ambient air temperature becoming the key determinant of the water temperature already in the headwaters. The scale of river water temperature variations depends on the air temperature. The higher the air temperature, the more rapidly the water temperature grows along the river course. In winter, at the time of extreme low air temperatures below $0^{\circ} \mathrm{C}$, the water upstream of the reservoir has a homogenous temperature of around $0^{\circ} \mathrm{C}$ (often with ice cover present).

2. Downstream from Klimkówka reservoir, the water temperature, affected by the thermal conditions within the reservoir, is significantly different than upstream. This is particularly pronounced in the summertime, when the water flowing out from the reservoir is cooler by more than ten degrees than the inflowing water. In winter, the situation is reversed: the water flowing out from the reservoir is warmer than the inflowing water. As a result, the relationship between the air temperature and the water temperature is weakened. The air temperature maintains its trend within the river valley 
along the river course in the given weather conditions. On the other hand, water temperatures downstream of the reservoir deviate significantly from the characteristics that water in this section of the Ropa river course would have naturally, in the absence of the reservoir. With growing distance downstream of the dam, the water temperature grows in summer and decreases in winter. This shows that, with growing distance from the dam, the ambient air temperature becomes the most important determinant of the river water temperature, despite a strong effect of the reservoir.

3. The Klimkówka reservoir disrupts the thermal continuity of the Ropa river. There is a new thermal profile of the river starting directly downstream of the reservoir.

In predicting potential effects of climate change on aquatic environment of rivers based on the relations between water and air temperature, distortions of those relations caused by reservoirs must be taken into consideration.

\section{REFERENCES}

[1] Caissie D. The thermal regime of rivers: a review, Freshwater Biology, 51, 2006, pp 1389-1406;

[2] Allan J. D. \& Castillo M. M. Stream ecology: structure and function of running waters. Springer Science \& Business Media, 2007;

[3] Mohseni O. \& Stefan H. G. Stream temperature/air temperature relationship: a physical interpretation, Journal of Hydrology, 1999, 218;

[4] Erickson T. R. \& Stefan H. G. Linear air/water temperature correlations in streams during open water periods, Journal of Hydrologic Engineering, ASCE. 5, 2000, pp 317321 ;

[5] Edinger J. E., Duttweiler D. W. \& Geyer J. C. The response of water temperatures to meteorological conditions, Water Resource Research, 4, 1968, pp 1137-1143;

[6] O'Driscoll M. A. \& DeWalle D. R. Stream-air temperature relations to classify stream-ground water interactions in a karst setting, central Pennsylvania, USA, Journal of Hydrolology, 329, 2006, 140-153;

[7] Soja R. \& Wiejaczka $Ł$. The impact of a reservoir on the physicochemical properties of water in a mountain river, Water and Environment Journal, 28, 2014, 473-482;

[8] Kędra M. \& Wiejaczka Ł. Disturbance of water-air temperature synchronisation by dam reservoirs, Water and Environment Journal, 2016, doi: 10.1111/wej.12156;

[9] Liu B., Yang D., Ye B. \& Berezovskaya S. Long-term open-water season stream temperature variations and changes over Lena River Basin in Siberia, Global and Planetary Change, 48, 2005, pp 96-111;

[10] Soja R. Termika wody w dorzeczu Ropy w okresie maksymalnych temperatur rocznych. Przegląd Geograficzny, 3, 1973, pp 587-597. 